\title{
A stressz és a fertilitás
}

\author{
Ősapay György dr. • Ősapay Klára dr.
}

University of California-Irvine, Irvine, CA, USA

\begin{abstract}
A nyugati világ országaiban az elmúlt évtizedekben a férfiak átlagos spermaszáma jelentősen csökkent és ezzel nemzőképességük is romlott. A női fertilitás tekintetében sem jobb a helyzet, és a „megmagyarázhatatlan meddőség” diagnózis egyre gyakoribb. A reproduktív funkciók egyre fokozódó, észrevehető defektusát az eddigi módszerekkel nem lehetett megmagyarázni. Évente 1 millió pár jelentkezik fertilitási kezelésre a világon, ami jelentős idő- és pénzráfordítást jelent a társadalomnak. Egyre nagyobb az igény a káros környezeti hatások, az életmódproblémák mélyebb megértésére és a testre szabott kezelések kifejlesztésére azok számára, akik a fogamzás esélyét növelni szeretnék. Az emocionális stresszorok hatását a reproduktív teljesítményre és annak tudományos alapjait Selye és munkacsoportja írta le 1976-ban. A kognitív terápiás módszerek rendszerint alkalmazhatók az emocionális stresszhatások ellen, az egészségmegőrzést célzó antioxidánsok, vitaminok és nyomelemek - különösen hiányuk esetén - pedig segítséget jelenthetnek a reproduktív egészségre káros reaktív oxigénvegyületek hatása ellen. Ésszerú és gazdaságos segítséget jelenthetnek a meddőség elleni küzdelemben még az orvosi beavatkozások szükségessége előtt. Orv. Hetil., 2015, 156(35), 1430-1434.
\end{abstract}

Kulcsszavak: fertilitás, meddőség, spermaképjavulás, Selye, stresszorok

\section{Stress and fertility}

In Western countries, sperm quality and fertility of men significantly worsened. Female infertility does not show a better trend either. Subtle defects in the reproductive functions can not be explained by the current methods, and "unexplained infertility" is becoming a more common diagnosis. Every year 1 million couples seek expensive and time consuming fertility treatment in the world. Deeper understanding of an unhealthy lifestyle and the environmental damages may lead to personalized treatments to increase the chance of conception. The effects of various stressors on the male and female reproductive performance were scientifically substantiated by Selye and coworkers in 1976. Cognitive therapy methods can be applied against emotional stressors, supplementation by antioxidants against reactive oxygen compounds, and administration of vitamins and trace elements, especially when deficiency is found, may help before medical intervention on a rational and economical way in the fight against infertility.

Keywords: infertility, sperm quality improvement, Selye, stressors

Ósapay, Gy., Osapay, K. [Stress and fertility]. Orv. Hetil., 2015, 156(35), 1430-1434.

(Beérkezett: 2015. június 4.; elfogadva: 2015. július 2.)

\section{Rövidítések}

ACTH $=$ adrenokortikotrop hormon; ART $=($ assisted reproduction technologies) mesterséges megtermékenyítés; CBT = cognitive-behavioural therapy; CRM = agyat stimuláló sugárterápia; $\mathrm{FHA}=$ funkcionális hypothalamicus amenorrhoea; $\mathrm{FSH}=$ (follicle stimulating hormone) tüszőérlelő hormon; $\mathrm{GH}=$ (growth hormone) növekedési hormon; GnRH = gonadotrop releasing hormon; HHMT = hypothalamus-hipofízismellékvese tengely; $\mathrm{LH}=$ (luteinizing hormone) sárgatest-képződést serkentő hormon; $\operatorname{Prl}=$ prolaktin
Statisztikai adatok szerint a fiatal párok 30\%-a nehezen vagy egyáltalán nem éri el a kívánt terhességet. Egyre gyakrabban előfordul, hogy egészséges, fiatal párok küzdenek meddőségi problémával. A meddőség alatt 12 hónapi sikertelen fogamzási próbálkozást értünk. Korábban a fogamzás nehézségeiért gyakrabban találtak okot a női partnerben, manapság azonos mértékben felelősek a nők és a férfiak (40-40\%), illetve egyidejűleg mindketten $(20 \%)$. 
A meddőséget gyakorta egészségügyi problémák okozzák, fertőzések, genetikai elváltozások, anatómiai problémák, immunológiai összeférhetetlenség, valamint a késői gyermekvállalásnál a párok megnövekedett életkora is. Általánosan elfogadott tény, hogy az egészségre, így a fertilitásra is, károsak a környezeti ártalmak, dohányzás, alkohol- és drogfogyasztás.

A meddőségi panaszok okainak kivizsgálásában, ha szervi, orvosi okok nem állapíthatók meg, azaz ismeretlen eredetű a meddőség, a következményként jelentkező endokrin zavarokat próbálják orvosolni, illetve a mesterséges megtermékenyítés (assisted reproduction technologies - ART) eszközeit vetik be. Kétségtelen, hogy az okok egyre kevésbé lesznek relevánsak, miközben a meddőségi központok ART-technikája mind sikeresebb lesz. Mindazonáltal az ovuláció és a fogamzás stimulálására, valamint a spermaminőség javítására alkalmazott gyógyszerek, hormonkészítmények gyakran nem mutatnak kellő eredményt, vagy éppen kellemetlen mellékhatásokkal járnak. A világon évente 1 millió pár jelentkezik fertilitási kezelésre, amely a társadalomnak jelentős idő- és anyagi ráfordítást jelent. A meddőség okainak további kutatása, valamint az ART-módszerek sikerességének fokozása érdekében érdemes a Selye-féle stresszelméletet feleleveníteni. A pszichoszomatikus okok feltárása és kezelése segítséget jelenthet nemcsak a párok fertilitási problémájában, de bizonyítottan az ART-módszerek sikerességében is $[1,2,3,4]$, valamint a zavartalan terhesség lefolyásában.

A személyiségfejlődés fontos része az egészséges pszichoszexuális fejlődés. Ha ebben zavaró hatások jelentkeznek, kihatással lesznek a reprodukciós képességre, sőt a párkapcsolatra is. A nem stabil párkapcsolat mindkét fél esetében gátolja a sikeres fogamzás létrejöttét. Az egzisztenciális bizonytalanság is egy gyakori stresszor, elsősorban a férfiakat érinti, hogy képesek lesznek-e eltartani leendő családjukat. Egy másik félelemként jelentkező stressztényező, amely mindkét félnél egyformán felmerülhet, hogy túlzott felelősséggel járhat a „babaprojekt” $[5,6,7]$. A mai gazdasági nehézségek között ez érthető, ez a leggyakoribb negatív tényező. A közelmúlt nagy gazdasági világválsága idején az Egyesült Államokban is szignifikánsan visszaesett a népszaporulat a felelősség kérdése miatt.

\section{Biológiai stressz-szindróma}

Selye professzor „különféle káros behatásokra fellépő szindróma" eseteivel kapcsolatos első kutatásairól 1936ban közölt cikket [8]. A behatásokra fellépő reakciókat később generális adaptációs szindrómának (általános alkalmazkodási tünetcsoportnak), illetve biológiai stresszszindrómának nevezte el. Mivel a stressz kifejezést a mindennapi nyelvben, de esetenként a szakirodalomban is, kétféle értelemben is használják, a továbbiakban Selye különválasztása szerint fogjuk használni. Stresszhatást jelentenek a szervezetet érő olyan külső körülmények, amelyek megítélésünk szerint megterhelők, veszélyeztetik fizikai és/vagy pszichikai jóllétünket, de lehetnek pozitívak is, azaz cselekvésre sarkallóak, amelyek jó irányba aktiválnak. A stresszválasz a stresszorok hatására, pozitív vagy negatív előjelü lehet, amit Selye eustressznek, illetve distressznek nevezett.

A stresszélettannal foglalkozó tanulmányok sorozatában Selye és munkatársainak 1976-ban jelent meg az a közleménye [9], amelyben állatkísérletekben vizsgálták a stressz és az adenohypophysis hormonjainak összefüggését. Nőstény patkányokat kényszerítettek mozdulatlanságra napi 8 órában, és a plazmában mérték a hormonszint változását $1,3,6,10$ és 15 nap után. A Selye által leírt sztereotip szindróma (több szervet érintő, egy időben fellépő elváltozáscsoport) ezekben a kísérletekben is jelentkezett: a mellékvesekéreg megnagyobbodott, túlmúködést mutatott, a csecsemómirigy és a nyirokcsomók zsugorodtak, sorvadtak, fekélyek keletkeztek a gyomorban és a bélrendszerben.

1936 óta nagy előrehaladás történt annak vizsgálatában, hogy mely hormonok közvetítik a stressz hatásait. A stresszorok hatására Selye szerint vészhelyzetben az adrenalinkiválasztás a kezdeti lépés. A homeosztázisnak, azaz a szervezet egyensúlyának a biztosításában legalább ilyen fontos szerepe van a hypothalamus-hipofízis-mellékvese tengelynek (HHMT). A stressz hatására izgalmi állapot jön létre a hypothalamusban, mire az serkenti a hipofízist, ACTH (adrenokortikotrop hormon) -szekréció történik. Az ACTH a mellékvese külső kérgi részében megindítja a kortikoidhormonok kiválasztását és sorvadást okoz a csecsemómirigyben és a nyirokcsomókban. Az 1976-ban megjelent Neuroendocrinology-cikk a hipofízis eltolódásának hipotézisét („hypophyseal shift theory") vizsgálta, azaz azt a feltételezést, hogy az ACTH-szekréció stressz általi aktiválása összefüggésben van a hipofízis - agyalapi funkciók - csökkenésével. A krónikus stressznek kitett állatokban a plazmában mért hormonszinteknél fordított arányt találtak a kortikoszteron (az ACTH-szekréció indexe) és a következő hormonok változása között: növekedési hormon (growth hormone - GH), sárgatest-képződést serkentő hormon (luteinizing hormone - LH), prolaktin ( $\mathrm{Prl}$ ) és kisebb mértékben a tüszőérlelő hormon (follicle stimulating hormone-FSH) (1. ábra).

\section{Stressz és meddőség 40 évvel Selye publikációja után}

A krónikus idegfeszültség, a kellemetlen és káros streszszek nagy csoportja, azaz amit Selye distressznek nevez, olyan hormonális változásokat eredményezhet, amelyek nem kedveznek a szaporodáshoz szükséges feltételeknek. Egyre nő azoknak a közleményeknek a száma, amelyek a meddőség okainak szempontjából vizsgálják a káros stresszorokat és azt, hogy hogyan javíthatók a stresszt okozó körülmények. 


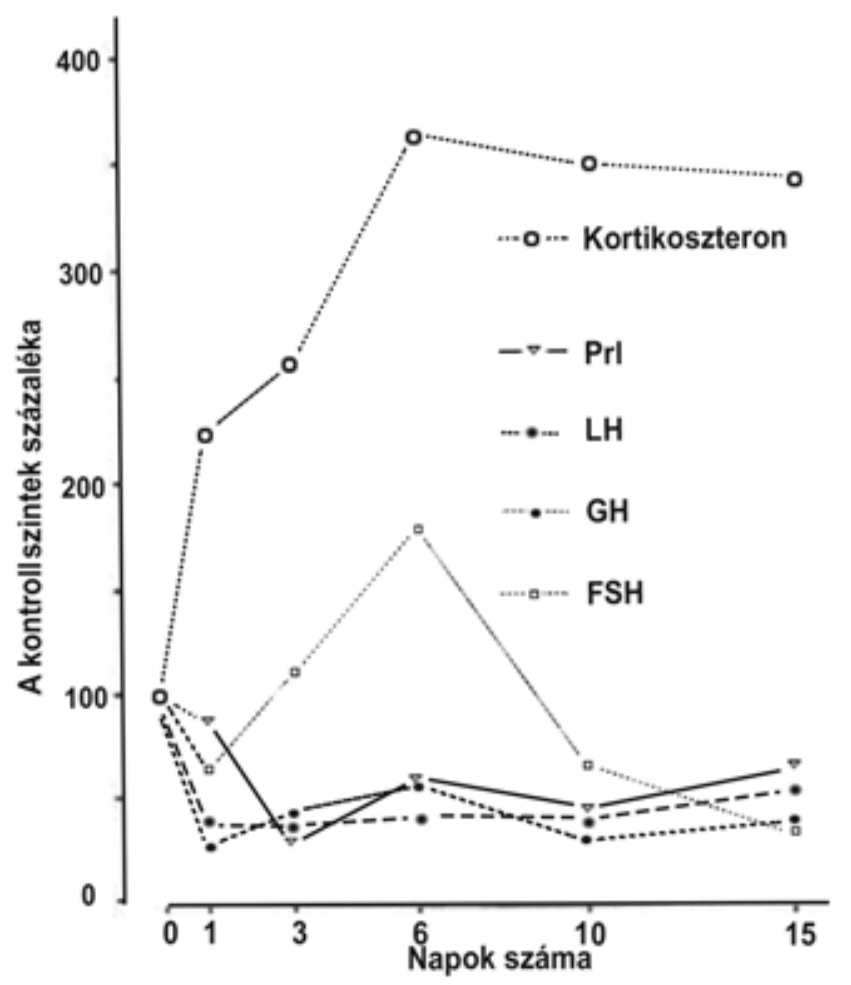

1. ábra

A napi 8 órás kényszerített mozdulatlanság hatása a plazma kortikoszteron-, GH-, Prl-, LH- és FSH-szintjére felnőtt nőstény patkányokon végzett kísérletben

Az utóbbi évtizedekben a globális éghajlati változások, az emberi beavatkozások és a környezeti szennyezések következményeként endokrin elváltozások valószínúsíthetők, amelyek fokozott stresszt jelentenek az ember szervezetére, így a reproduktív funkciókra is. Tanulmányok ezrei értekeznek a stressznek az orvosi, mezőgazdasági és alapbiológiai aspektusáról és a reproduktív funkciók elsorvadásáról. Meg kell természetesen azt is jegyezni, hogy egyre több a példa arra, hogy egyes állatfajták ellenállnak a környezeti és szociális stressznek, mivel a klasszikus „trade-off” miatt a potenciális túlélést a reproduktív siker biztosítja [10].

Érdekes megfigyelés, hogy az extrém pszichés streszszorok milyen következményekkel járnak a HHMT aktivitására és a reproduktív funkciókra [11]. Amenorrhoea következett be nemi erőszakon átesett nők 10\%-ánál, kivégzésre ítélt nők 100\%-ánál. A háborúkban és a koncentrációs táborokban pedig a menstruációs, a reprodukciós funkciók 50\%-ban sérültek. A nőknél a káros stressz hatása hamar észrevehető: a fizikai és lelki streszszorok a hypothalamus szintjén amenorrhoeát, menstruációs zavarokat okozhatnak [12].

A stresszhatások befolyásolják a hypothalamus-hipofízis-petefészek tengelyt, megzavarhatják az ovulációt és a ciklust [13]. Ugyanígy a fizikai stressz: túlzott sportolás, túl alacsony kalóriafogyasztás a menstruációs ciklus rendjét felboríthatja [12], következtében több hónapos menstruációs szünet következhet be, ami természetesen a termékenységet befolyásolja.
Négy éven át tartó prospektív kohorsztanulmányban [14] a szerzók olyan párok sorsát követték, akik fogamzásra készültek. A tanulmányban a stressz mértékét a nyál kortizol- és alfa-amiláz-szintjének mérésével ellenőrizték, amit havi rendszerességgel mértek 12 hónapon keresztül. 401 pár fejezte be a vizsgálatot, közülük 347 (87\%) ért el terhességet. A kortizolmérésekkel ellentétben az alfa-amiláz-szintek korrelációt mutattak a terhesség elmaradásának valószínúségével (2.ábra).

\section{Pszichoszociális beavatkozás}

Az elmúlt évtizedekben számos szakcikk jelent meg a pszichoszociális beavatkozások hatásosságáról, amelyekben az alkalmazott eljárásokkal eredményt értek el meddőséggel küzdő nók és férfiak eseteiben. 2014-ben jelent meg Frederiksen és munkatársainak review cikke, amely 1978 és 2014 között végzett 39 kutatás eredményeinek metaanalízisét prezentálja [15]. A kutatásokban 3064 nő és 347 férfi vett részt, akik különféle, 1 héttól 6 hónapig tartó pszichoszociális kezelést kaptak. Az eredmények analízise kimutatta, hogy infertilis párok ilyen módon történő kezelése, kiemelten a kognitív viselkedésterápia (cognitive-behavioural therapy - CBT) hatékony lehet mind a pszichológiai distressz, mind a klinikai fogamzási arány növelése terén. A pszichoszociális beavatkozások pszichológiai eredményei a kutatások eredményei szerint

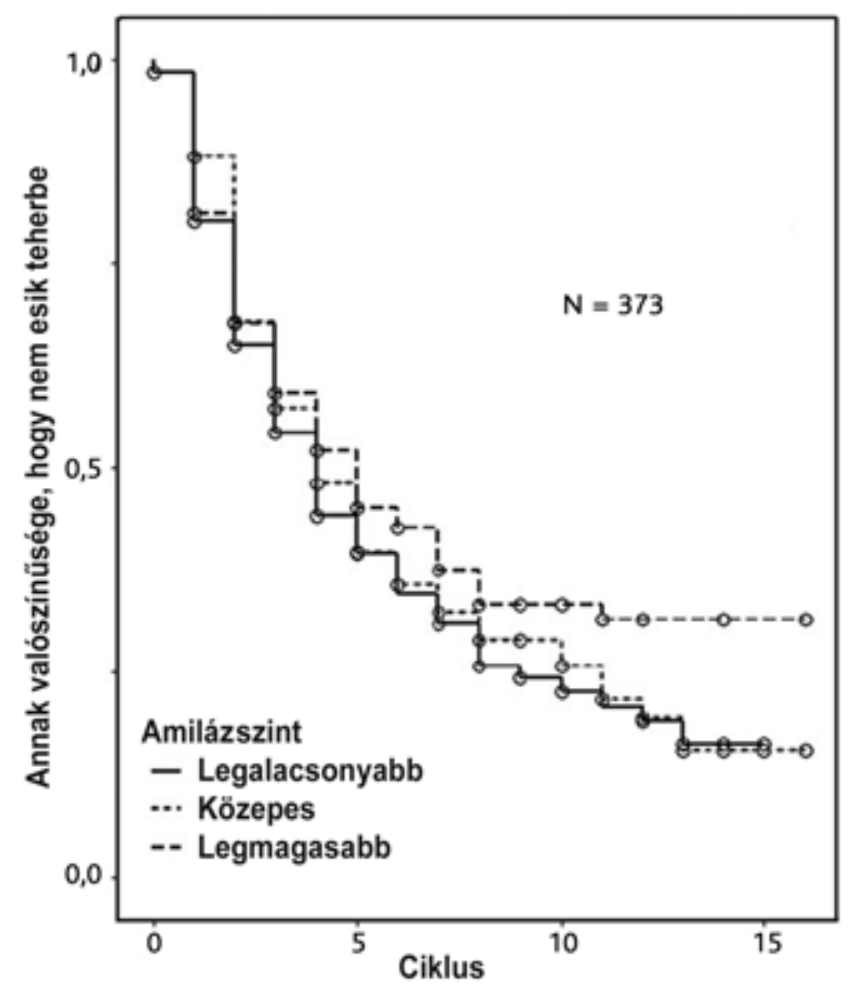

\begin{tabular}{l|l} 
2. ábra & Annak valószínúsége, hogy nem következik be terhesség - a
\end{tabular} nyálban mért alfa-amiláz-szint függvényében. Korrekció történt a női partner életkora, a férfi és nő közötti korkülönbség, a női partner jövedelme, a népcsoport, a dohányzás, a koffein- és alkoholfogyasztás szerint 
jónak mondhatók, a kezelések csökkentették a szorongást (25 tanulmány), valamint a depresszió tüneteit (21 tanulmány). A nókre vonatkozó vizsgálatok (10 tanulmány) szerint a pszichológiai kezelések mintegy kétszeresére növelték a fogamzások számát a nem kezelt női kontrollcsoporthoz képest.

$\mathrm{Az}$ anovuláció reverzíbilis formája a funkcionális hypothalamicus amenorrhoea (FHA), proximalis okozója a csökkent gonadotrop releasing hormon (GnRH) termelődés, amely csökkent LH- és FSH-szintekben manifesztálódik. FHA-ban szenvedő nők esetében a HHMT aktiválódik, amelyet a keringésben és a cerebrospinalis folyadékban lévő kortizolszint növekedése kísér [16]. FHA-ból való gyógyulás után a szérum kortizolszintje csökkent. Randomizált, kontrollált vizsgálatot végeztek olyan, FHA-ban szenvedő nőkön, akiknél az anovulációnak nem volt szervi oka. A kísérletből kizáró ok volt a pszichiátriai megbetegedés, túlzott fizikai terhelés, evésialvási rendellenesség, gyógyszerfüggés. A betegek fele random kiválasztás szerint kognitív viselkedésterápiában (CBT) vett részt, a kontrollcsoport csak megfigyelés alatt állt. 20 héten át heti gyakorisággal vérminta vizsgálatára került sor. Az eredmények szerint a CBT-ben részesült nők 81\%-ánál az ovuláció teljes mértékben helyreállt, a kontrollcsoportban csak 33\%-ban volt részleges gyógyulás. A CBT-vel kezelt csoportban a kortizolszint csökkent a kontrollhoz képest, a leptinszint pedig emelkedett. Az eredmények alapján a viselkedésterápia neuroendokrin rendellenességeket volt képes korrigálni [17].

\section{Stressz és csökkent nemzőképesség}

Az elmúlt évtizedekben a férfiak nemzőképessége jelentősen romlott, amit az ondósejtszám csökkenése is jelez. Észak-Amerikában 1938 óta az átlagos spermiumszám csökkenése évi 1,5\%, Európában 3,1\%. Czeizel Endre mérései alapján az 1960-as években a magyar férfiaknak még 74 millió ondósejtjük volt az ondófolyadék egy milliliterében [18], az 1990-es évekre ez 31 millióra csökkent, és a spermiumok mozgékonysága is gyengült.

A párok sikertelen fogamzási próbálkozásának orvosi vizsgálata az esetek mintegy felében kimutatta a férfi partner spermaképének hiányosságát. A spermakép (spermiumok száma, alakja és mozgékonysága) az utóbbi negyven évben sokat rosszabbodott a magyar férfiak jelentős hányadánál. A probléma megoldására legtöbb esetben van segítség, azonban az ART-programokban való részvétel elhatározása előtt ajánlott kipróbálni először az életmód megváltoztatását (relaxálás, étrend- és mikrotápanyag-bevitel optimálása, testmozgás). Sok esetben elegendő lehet a szervezetet terhelő, túlsúlyba került oxidatív gyökök közömbösítése antioxidánsokkal, ami által a szervezet kémiai, azaz oxidatín szöpetkárosodása („stressze") csökkenthető. Oxidatív stressz alatt azt az állapotot értjük, amikor a szervezetben lévő oxidatív reaktív gyökök és az antioxidáns védekezőanyagok aránya az előbbiek irányába tolódik el. A kutatások igazolták az antioxidánsok spermaképjavító eredményességét, a természetes összetevőket (vitaminok, nyomelemek, növényi drogok) és sok antioxidánst alkalmazó kezelési programok jelentősen növelték a spermiumok számát, mozgékonyságát [18].

A férfiak megtermékenyítőképességére az emocionális stressz ugyancsak káros hatással van. Collodel és munkatársainak kutatásában idiopathiás infertilis férfiakon végeztek stresszterápiát [19]. Valamennyi résztvevőnél (20 személy) a kezdeti vizsgálatok szerint egyértelmú volt a pszichológiai stresszes állapot. A szerzők megállapítása szerint a fennálló stressz a spermiumok meioticus és strukturális módosulását eredményezte. A csoport felénél agyat stimuláló sugárterápiát (CRM) alkalmaztak, és a 3 hónappal későbbi vizsgálat igazolta a spermatogenesis, végeredményben a spermakép jelentős javulását. Megállapítható volt, hogy az emocionális stressz az idiopathicus infertilitás kockázati faktora.

\section{Következtetés}

Megállapítható, hogy mind az emocionális, mind a környezeti stresszhatások jelentősen csökkenthetik a férfi és női fertilitást. Ennek ellensúlyozására a pszichoszomatikus okok feltárása és kezelése segítséget jelenthet. A kognitív terápiás módszerek rendszerint alkalmazhatók az emocionális stresszorok ellen, az egészségmegőrzést célzó antioxidánsok, vitaminok és hiányt pótló nyomelemek pedig támogatást nyújtanak a reproduktív egészséghez a megtermékenyítés, illetve a fogamzás előtti időszakban. Ésszerű és gazdaságos segítséget jelenthetnek a meddőségi problémákban még az orvosi beavatkozások szükségessége előtt.

Anyagi támogatás: A közlemény megírása anyagi támogatásban nem részesült.

Szerzői munkamegosztás: A cikk elkészítéséhez a szerzők egyenlő arányban járultak hozzá, végleges változatát elolvasták és jóváhagyták.

Érdekeltségek: A szerzőknek nincsenek érdekeltségeik.

\section{Köszönetnyilvánítás}

Köszönetet mondunk Dr. Szabó Sándor professzor úrnak a témafelve tésért, és hogy a Selye professzor által kezdeményezett témára irányította figyelmünket.

\section{Irodalom}

[1] Stoleru, S., Cornet, D., Vaugeois, P., et al.: The influence of psychological factors on the outcome of the fertilization step of in vitro fertilization. J. Psychosom. Obstet. Gynaecol., 1997, 18(3), 189-202. 
[2] Demyttenaere, K., Bonte, L., Gheldof, M., et al.: Coping style and depression level influence outcome in vitro fertilization. Fertil. Steril., 1998, 69(6), 1026-1033.

[3] Facchinetti, F., Matteo, M. L., Artini, G. P., et al.: An increased vulnerability to stress is associated with a poor outcome of in vitro fertilization-embryo transfer treatment. Fertil. Steril., 1997, 67(2), 309-314.

[4] Domar, A. D., Clapp, D., Slawsby, E. A., et al.: Impact of group psychological interventions on pregnancy rates in infertile women. Fertil. Steril., 2000, 73(4), 805-811.

[5] Greil, A. L., Slauson-Blevins, K., McQuillan, J.: The experience of infertility: a review of recent literature. Sociol. Health Illn., 2010, 32(1), 140-162.

[6] Greil, A. L.: Infertility and psychological distress: a critical review of the literature. Soc. Sci. Med., 1997, 45(11), 1679-1704.

[7] Stanton, A. L., Lobel, M., Sears, S., et al.: Psychosocial aspects of selected issues in women's reproductive health: current status and future directions. J. Consult. Clin. Psychol., 2002, 70(3), 751-770.

[8] Selye, H.: A syndrome produced by diverse nocuous agents. Nature, 1936, 138, 32.

[9] Taché, Y., Du Ruisseau, P., Taché, J., et al.: Shift in adenohypophyseal activity during chronic intermittent immobilization of rats. Neuroendocrinology, 1976, 22(4), 325-336.

[10] Wingfield, J. C., Sapolsky, R. M.: Reproduction and resistance to stress: when and how. J. Neuroendocrinol., 2003, 15(8), 711724 .

[11] De Bellis, M. D., Chrousos, G. P., Dorn, L. D., et al.: Hypothalamic-pituitary-adrenal axis dysregulation in sexually abused girls. J. Clin. Endocrinol. Metab., 1994, 78(2), 249-255.

[12] Bachmann, G. A., Kemmann, E.: Prevalence of oligomenorrhea and amenorrhea in a college population. Am. J. Obstet. Gynecol., $1982,144(1), 98-102$.
[13] Chrousos, G. P., Torpy, D. J., Gold, P. W.: Interactions between the hypothalamic-pituitary-adrenal axis and the female reproductive system: clinical implications. Ann. Intern. Med., 1998, 129(3), 229-240.

[14] Lynch, C. D., Sundaram, R., Maisog, J. M., et al.: Preconception stress increases the risk of infertility: results from a couple-based prospective cohort study - the LIFE study. Hum. Reprod., 2014, 29(5), 1067-1075.

[15] Frederiksen, Y., Farver-Vestergaard, I., Skovgaird, N. G., et al.: Efficacy of psychosocial interventions for psychological and pregnancy outcomes in infertile women and men: a systematic review and meta-analysis. BMJ Open, 2015, 5(1), e006592. doi: 10.1136/bmjopen-2014-006592. [Accepted 15 December 2014]

[16] Berga, S. L., Daniels, T. L., Giles, D. E.: Women with functional hypothalamic amenorrhea but not other forms of anovulation display amplified cortisol concentrations. Fertil. Steril., 1997, 67(6), 1024-1030.

[17] Michopoulos, V., Mancini, F., Loucks, T. L., et al.: Neuroendocrine recovery initiated by cognitive behavioral therapy in women with functional hypothalamic amenorrhea: a randomized controlled trial. Fertil. Steril., 2013, 99(7), 2084-2091.el.

[18] Horváth, M., Czeizel, E.: Effect of new dietary supplement on sperm quality. [Új gyógyhatású készítmény hatása az ondósejtképzésre.] Orv. Hetil., 2012, 153(45), 1787-1792. [Hungarian]

[19] Collodel, G., Moretti, E., Fontani, V., et al.: Effect of emotional stress on sperm quality. Indian J. Med. Res., 2008, 128(3), 254261.

(Ösapay György dr., Budapest, Teréz krt. 20., 1066 e-mail: gosapay@uci.edu)

\section{Tisztelt Szerzőink, Olvasóink!}

Az Orvosi Hetilapban megjelenő/megjelent közlemények elérhetöségére több lehetőség kínálkozik.

Rendelhetö különlenyomat, melynek áráról bővebben a www.akkrt.hu honlapon (Folyóirat Szerzöknek, Különlenyomat menüpont alatt) vagy Szerkesztőségünkben tájékozódhatnak.

A közlemények megvásárolhatók pdf-formátumban is, illetve igényelhető Optional Open Article (www.oopenart.com).

Adott dij ellenében az online közlemények bárki számára hozzáférhetök honlapunkon (a közlemények külön linket kapnak, így más oldalról is linkelhetővé válnak).

Bővebb információ a hirdetes@akkrt.hu címen vagy különlenyomat rendelése esetén a Szerkesztőségtől kérhető. 